\title{
Distribution of Protein I, a Synapse-Specific Phosphoprotein, and Adenylate Cyclase in the Rat Spinal Cord
}

\author{
Tetsufumi Ueda, Carol A. Stratford, and James Larson \\ Mental Health Research Institute and the Departments of Psychiatry and Pharmacology, \\ The University of Michigan, Ann Arbor, Michigan, U.S.A.
}

\begin{abstract}
The longitudinal and transverse distributions of the synapse-specific phosphoprotein Protein I and adenylate cyclase in the rat spinal cord were studied. Protein I was found to be enriched in all cervical and midlumbar $\left(\mathrm{L}_{3}-\right.$ $\mathrm{L}_{\text {.) }}$ ) segments, and sparse in midthoracic and sacral segments. Adenylate cyclase activity was high in all cervical and lumbosacral segments, and low in midthoracic segments. Cross-sectionally, both Protein I and adenylate cyclase were more enriched in the dorsal half than in the ventral half in the various segments studied. The similar topographical distributions of Protein I and adenylate cyclase in the spinal cord support the idea that adenylate cyclase may be intimately associated with Protein I in the nervous system, and could thereby regulate the state of in vivo phosphorylation of Protein I through formation of cyclic AMP. Key words: Cyclic AMP-regulated phosphoproteinProtein I-Synapse-Adenylate cyclase-Spinal cord. Ueda T. et al. Distribution of Protein I, a synapse-specific phosphoprotein, and adenylate cyclase in the rat spinal cord. J. Neurochem. 36, 293-296 (1981).
\end{abstract}

Protein Ia (mol. wt. $=86,000)$ and Protein Ib (mol. wt. $=80,000$ ), collectively referred to as Protein 1 because of their highly similar properties (Ueda and Greengard, 1977), are principal endogenous substrates for cyclic AMP-dependent protein kinase in membrane fractions derived from synaptic structures (Ueda et al., 1973; Ueda and Greengard, 1977; Lohmann et al., 1978; De Blas et al., 1979; Kelly et al., 1979; Walter et al., 1979). They are not only associated with synaptic membranes, but also highly enriched in synaptic vesicles and postsynaptic densities (Bloom et al., 1979; Ueda et al., 1979). This synaptic localization of Protein $I$ is consistent with the notion that cyclic AMP-dependent phosphorylation of Protein I may be involved in mediating the action of monoamine neurotransmitter-sensitive adenylate cyclases in certain types of synapses (Greengard, 1976; Kanof et al., 1977; Greengard, 1978; 1979). However, in order for the cyclic AMP-dependent phosphorylation of
Protein I to be able to play such a physiological role, Protein I must be localized proximally to adenylate cyclase (EC 4.6.1.1) and associated with monoaminergic synapses. Herein we report studies on the distribution of Protein I and adenylate cyclase, and on the activation of the former by monoamines in the rat spinal cord in an effort to assess their topographic relationship.

\section{MATERIALS AND METHODS}

\section{Materials}

$\left[\gamma^{-32} \mathrm{P}\right]$ ATP was obtained from New England Nuclear (Boston, Massachusetts): $\left[\alpha_{-}^{-32} \mathrm{P}\right] \mathrm{ATP}$ from ICN (Irvine, California); ATP (disodium form), sodium dodecyl sulfate (SDS), and 4-(2-hydroxyethyl)-1-piperazineethane sulfonic acid (HEPES), and cyclic AMP from Sigma (St.
Received February 25. 1980; accepted June 30, 1980.

Address correspondence and reprint requests to Tetsufumi Ueda, Mental Health Research Institute, The University of Michigan, 205 Washtenaw Place, Ann Arbor, Michigan 48109.
Abbreviations used: HEPES, 4-(2-hydroxyethyl)-1-piperazineethane sulfonic acid; SDS, Sodium dodecylsulfate. 
Louis, Missouri): guanylylimidodiphosphate from ICN (Irvine, California); and isobutylmethyl xanthine from Calbiochem (La Jolla, California).

\section{Preparation of a Total Particulate Fraction and its Acid Extract from Spinal Cord Segments}

Rats (male Sprague-Dawley, 350-500 g) were anesthetized with diethyl ether; the entire spinal cord was removed together with the enveloping vertebrae, and the cord was sectioned using the vertebrae as landmarks. The cord segments were then detached from the vertebrae. The relationship of the vertebral segments and spinal cord segments of the adult rat has been described in detail by Waible (1973). The spinal cord segments were homogenized in 20 volumes of $5 \mathrm{~mm}-\mathrm{Tris}-\mathrm{HCl}(\mathrm{pH} 7.4)$ in a Teflon-glass homogenizer ( 12 strokes at 1200 r.p.m.) and centrifuged at $150,000 \times g$ for $30 \mathrm{~min}$ to obtain the total particulate fraction. The particulate fraction (which contained virtually all of Protein I present in the homogenate) was suspended and homogenized in the original volume of $5 \mathrm{~mm}$-Tris- $\mathrm{HCl}(\mathrm{pH} 7.4)$.

\section{Assay of Protein I}

Protein I was extracted by acidification to $\mathrm{pH} 3$ (Ueda and Greengard, 1977), followed by the readjustment of $\mathrm{pH}$ to 6 (Lohmann et al., 1978). The amount of dephosphoprotein in the $\mathrm{pH} 6$ supernatant I was assayed by determining the amount of $\left.{ }^{32} \mathrm{P}\right]$ phosphate incorporated into Protein $I$ in the presence of an excess of $\left[\gamma^{-32} \mathrm{P}\right] A T P, c y-$ clic AMP and added protein kinase, as described previously (Ueda and Greengard, 1977). Each pH 6 supernatant was assayed in duplicate. The range of variation was less than 5\%. Most, if not all, of the Protein $\mathrm{I}$ in the $\mathrm{pH} 6$ supernatant was in a dephosphorylated form, since the amount of $\left[{ }^{32} \mathrm{P}\right]$ phosphate incorporation into Protein I was not significantly affected by treatment of the $\mathrm{pH} 6$ supernatant (derived from several spinal segments) with sufficient amounts of protein phosphatase [purified through step 4 of the procedure of Chou et al. (1977)] prior to the in vitro phosphorylation assay. Therefore, the amount of [ ${ }^{32}$ P]phosphate incorporated into Protein I under the assay conditions used was considered to represent the amount of total Protein I in the $\mathrm{pH} 6$ supernatant. Protein concentration was determined by the method of Lowry et al. (1951) with bovine serum albumin as protein standard.

\section{Assay of Adenylate Cyclase}

Aliquots ( $30 \mu \mathrm{l}, 85 \mu \mathrm{g}$ protein) of the homogenate of the particulate fraction after $150,000 \times g$ centrifugation were assayed for adenylate cyclase activity in the reaction mixture (final volume, $100 \mu \mathrm{l}$ ) which contained $50 \mathrm{~mm}$ -

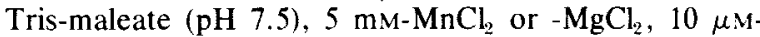
guanylylimidodiphosphate, $2 \mathrm{~mm}$-dithiothreitol, $1 \mathrm{~mm}$ isobutylmethyl xanthine, and $1 \mathrm{~mm}-\left[\alpha{ }^{-32} \mathrm{P}\right]$ ATP $(10-30$ $\mathrm{mCi} / \mathrm{mmol}, \mathrm{pH}$ adjusted to 7.4 with Tris base). The enzyme reaction, initiated by the addition of $\left[\alpha^{-32} \mathrm{P}\right] \mathrm{ATP}$ in $10 \mu \mathrm{l}$, was allowed to proceed for $5 \mathrm{~min}$ at $30^{\circ}$, and was terminated by the addition of $100 \mu$ l of an "SDS mixture" containing $6 \%$ SDS, $3 \mathrm{~mm}$-cyclic AMP, and $2 \mathrm{mM}$-ATP $\left(\mathrm{pH} \mathrm{7.0)}\right.$. Cyclic $\left.{ }^{32} \mathrm{P}\right] \mathrm{AMP}$ produced was isolated and quantitated by the method of Salomon et al. (1974). Each sample was assayed in triplicate. The range of variation was less than $10 \% . \mathrm{MnCl}_{2}$ was used to assess the total adenylate cyclase activity, in view of evidence (Ross et al., 1978; Neer, 1979) that $\mathrm{Mn}^{2+}$ activates the minimal catalytic component of the enzyme by bypassing hormone receptor and additional regulatory components. In

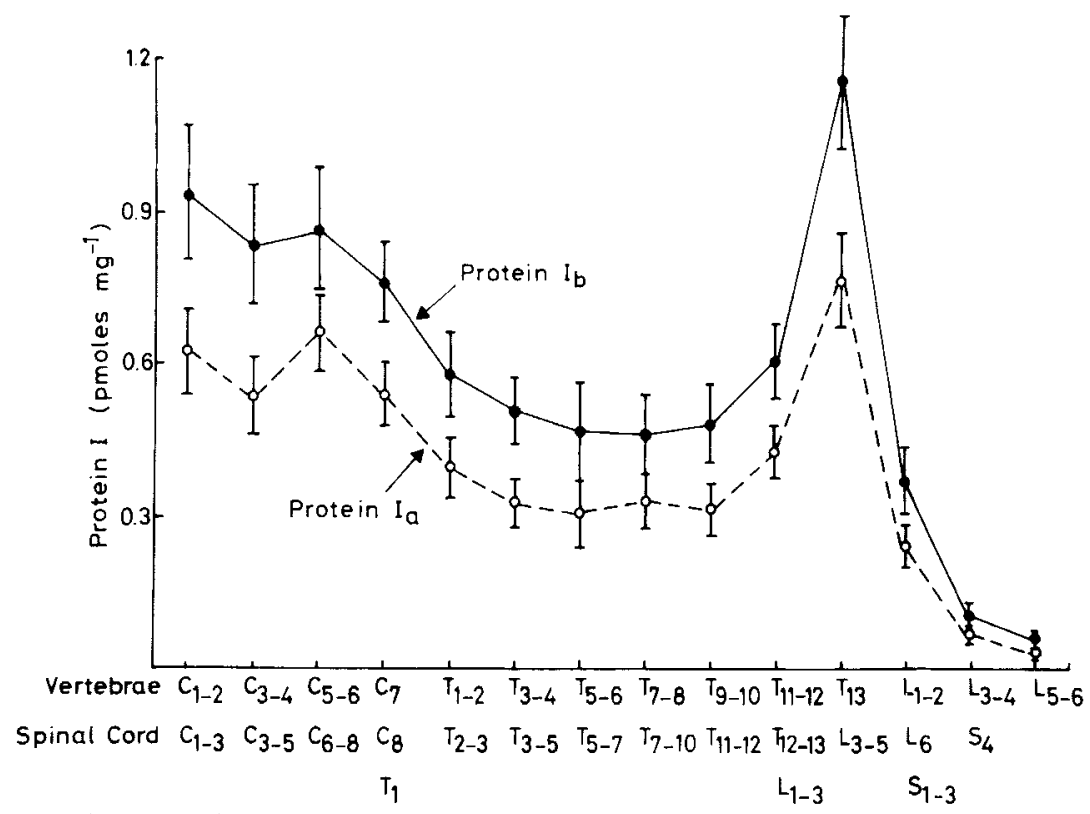

FIG. 1. Segmental quantitative analysis of Protein la and Protein $\mathrm{lb}$ in the rat spinal cord. Proteins la and $\mathrm{lb}$ in various spinal cord segments indicated were assayed as described under Materials and Methods. Specific amounts of Protein la and Protein Ib are expressed as pmol per $\mathrm{mg}$ of protein in each total particulate fraction. Each point represents the mean \pm S.E.M. Of a determination on 10 or 11 animals. $\mathrm{O}-\mathrm{O}$. Protein la; - Protein $\mathrm{lb}$. 
some experiments, various segments of the spinal cord were homogenized in 50 volumes of $2 \mathrm{~mm}$-Tris-maleate (pH 7.4) -2 mM-EGTA, and aliquots ( $20 \mu$ g protein) were assayed for adenylate cyclase in the presence of $0.1 \mathrm{~mm}$ concentrations of various monoamines or adenosine by the method of Kebabian et al. (1972), with the following modifications: $0.5 \mathrm{~mm}-\left[\alpha_{-}{ }^{32} \mathrm{P}\right] \mathrm{ATP}$ was used, the final incubation volume was $100 \mu \mathrm{l}$, and cyclic AMP was analyzed by the method of Salomon et al. (1974).

\section{RESULTS AND DISCUSSION}

The longitudinal distribution of Protein Ia and Protein Ib in the rat spinal cord is shown in Fig. 1. Although the rat spinal cord was sectioned using vertebrae as landmarks, spinal segments referred to hereafter are those segments which are recognized by respective spinal nerve attachments. Both Protein Ia and Protein Ib showed similar distribution patterns along the spinal cord. The concentrations of both Protein Ia and Protein Ib were high in all the cervical segments $\left(C_{1}-C_{8}\right)$ and low in most of the thoracic segments $\left(\mathrm{T}_{2}-\mathrm{T}_{13}\right)$. In the lumbosacral region, Protein Ia and Protein Ib were highly localized in the midlumbar region $\left(L_{3}-\mathbf{L}_{5}\right)$, whereas little was found in the sacral segments $\left(S_{1}-S_{4}\right)$. This indicates that Protein I is not necessarily distributed in direct proportion to gray matter; the sacral segments, which have a higher proportion of gray matter than the midlumbar segments (Waible, 1973), contain smaller amounts of Protein 1 than the midlumbar segments. The unique distribution of Protein I did not parallel the distribution of norepinephrine or dopamine in the spinal cord (data not shown: also see Bingham et al., 1975; Rawe et al., 1977).

Cross-sectionally, Protein I was found to be more en-
TABLE 1. Dorso-ventral distribution of Protein I and adenylate cyclase in various segments of rat spinal cord

\begin{tabular}{lcc}
\hline & \multicolumn{2}{c}{ Dorsal/ventral concentration ratio } \\
\cline { 2 - 3 } \multicolumn{1}{c}{ Segments } & Protein I & Adenylate cyclase \\
\hline Cervical & $1.6 \pm 0.2$ & $1.8 \pm 0.7$ \\
Thoracic & $4.7 \pm 2.0$ & $3.9 \pm 1.8$ \\
Lumbar & $2.3 \pm 0.3$ & $2.8 \pm 1.0$ \\
Lumbosacral & $1.5 \pm 0.1$ & $1.9 \pm 0.4$ \\
\hline
\end{tabular}

The cervical $\left(\mathrm{C}_{1}-\mathrm{C}_{2}\right)$, thoracic $\left(\mathrm{T}_{5}-\mathrm{T}_{7}\right)$, lumbar $\left(\mathrm{L}_{3}-\mathrm{L}_{5}\right)$, and lumbosacral $\left(L_{6}, S_{1}-S_{3}\right)$ segments of the rat spinal cord were divided into the dorsal and ventral halves, and the specific amount and activity of Protein I and adenylate cyclase, respectively, were determined as described in Materials and Methods. Values are mean \pm S.E.M. on three rats.

riched in the dorsal than in the ventral portion (Table 1). Immunocytochemical evidence recently obtained indicates that Protein I is highly localized in laminae I and II of Rexed within the dorsal horn where sensory inputs occur (S. Watson and T. Ueda, unpublished observation). This is again in contrast to the distribution of norepinephrine and serotonin; they are more enriched in the ventral than in the dorsal horn at cervical and lumbar levels, and most enriched in the lateral horn at thoracic levels (Carlsson et al., 1964; Zivin et al., 1975).

The nonparallel distributions, both longitudinal and transverse, of Protein I, catecholamines, and serotonin in the spinal cord suggest that Protein I may not be primarily associated with catecholaminergic or serotonergic synapses. This interpretation is consistent with the ob-

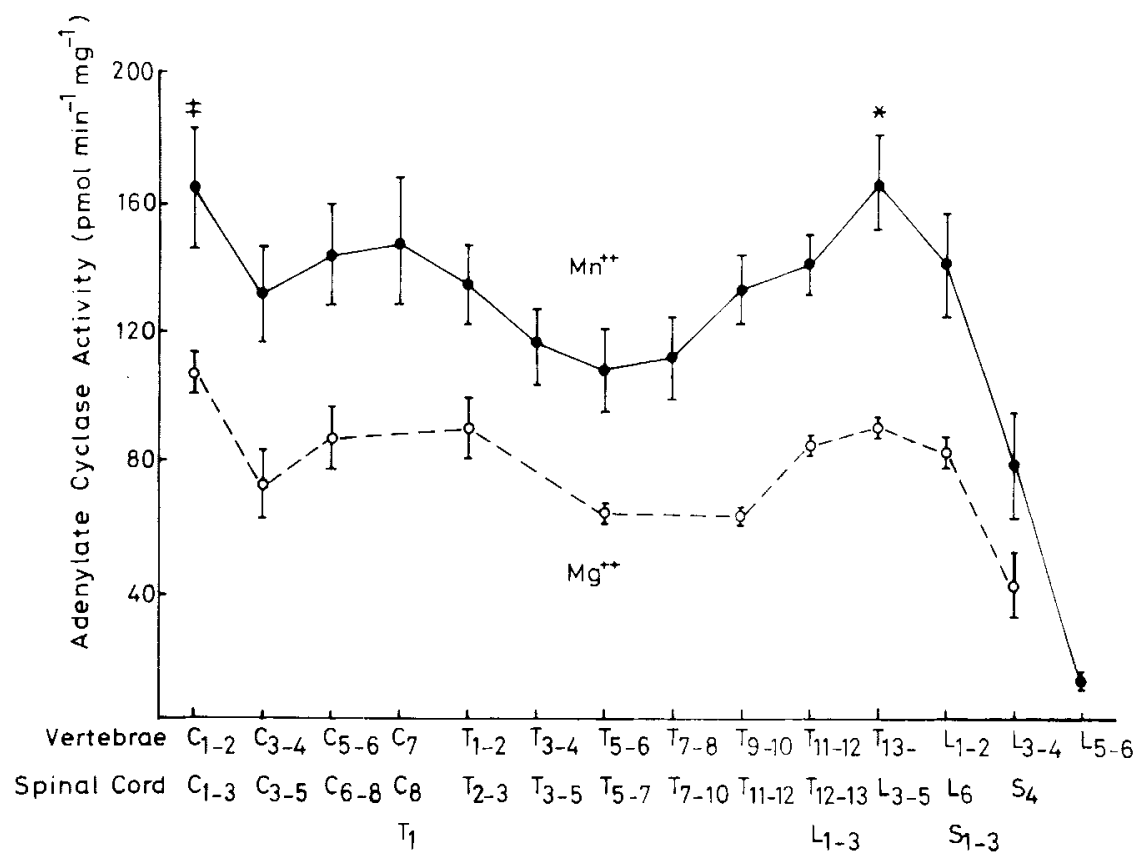

FIG. 2. Segmental determination of adenylate cyclase activity in the rat spinal cord. Adenylate cyclase in various spinal cord segments indicated was assayed, in the presence of $5 \mathrm{mM}-\mathrm{MnCl}_{3}$ or $\mathrm{MgCl}_{2}$, as described under Materials and Methods. Specific activity of adenylate cyclase is expressed as pmol cyclic AMP formed per min per $\mathrm{mg}$ protein in each total particulate fraction. Each value represents the mean \pm S.E.M. Of determinations on five animals $\left(-, \mathrm{MnCl}_{2}\right)$ and on three animals $\left(\mathrm{O}-\mathrm{O}\right.$. $\left.\mathrm{MgCl} \mathrm{C}_{2}\right)$. Significantly different from midthoracic segments $\left(T_{5}-T_{7}\right)$ : ${ }^{*}, P<0.01 ; \ddagger, P<0.025$. 
servation (Bloom et al., 1979) that the density and distribution of catecholamine-containing nerve terminals did not entirely agree with the occurrence of anti-Protein I immunoreactive terminals.

The longitudinal distribution of adenylate cyclase in the spinal cord is shown in Fig. 2. Relatively high adenylate cyclase activity was found in cervical. lumbar, and upper sacral segments, and relatively low activity was found in midthoracic segments. This distribution pattern is in reasonable agreement with that of Protein I; the highest adenylate cyclase activity was found in those segments in which Protein I was most enriched, with low activity found in those segments in which Protein I content was low. Although $\mathrm{Mn}^{2-}$ substantially activated adenylate cyclase in the spinal cord, norepinephrine, dopamine, serotonin, histamine, or adenosine had no significant effect on the enzyme activity in the homogenates of various segments of the spinal cord when tested at $0.1 \mathrm{~mm}$ under assay conditions similar to those described by Kebabian et al. (1972) (data not shown). We may mention, however, that Jones and McKenna (1980) have recently reported that norepinephrine significantly increases levels of cyclic AMP in spinal cord slice preparations.

Cross-sectionally, adenylate cyclase was found to be more enriched in the dorsal than in the ventral part at all the levels studied (Table 1). The table also shows that the cross-sectional distribution patterns of adenylate cyclase at the various levels are similar to those of Protein I.

The similar topographical distributions reported here of Protein I and adenylate cyclase in the spinal cord support the idea that adenylate cyclase may be intimately associated with Protein $I$ in the nervous system and could thereby regulate the state of in vivo phosphorylation of Protein I through formation of cyclic AMP. However, a physiological activator(s) of adenylate cyclase functionally linked to Protein I remains to be identified.

\section{ACKNOWLEDGMENT}

This work was supported by a grant (NS 15113 to T.U.) from the United States Public Health Service. C.A.S. is supported by USPHS Predoctoral Training Grant GM 07767. We thank Robert Rosenbaum and Giulio Baldrighi for valuable technical assistance.

\section{REFERENCES}

Bingham W. G., Ruffolo R., and Goodman J. H. (1975) Norepinephrine and dopamine levels in normal dog and monkey spinal cord. Life Sci. 16, 1521-1526.

Bloom F. E.. Ueda T.. Battenberg E., and Greengard P. (1979) Immunocytochemical localization, in synapses, of protein I, an endogenous substrate for protein kinases in mammalian brain. Proc. Natl. Acad. Sci. USA 76, 5982-5986.

Carlsson A., Falck B., Fuxe K., and Hillarp N-A. (1964) Cellular localization of monoamines in the spinal cord. Acta Physiol. Scand. 60, 112-119.

Chou C. K., Alfano J., and Rosen O. M. (1977) Purification of phosphoprotein phosphatase from bovine cardiac muscle that catalyzes dephosphorylation of cyclic AMP binding protein component of protein kinase. J. Biol. Chem. 252, $2855-2859$.
De Blas A. L., Wang Y-J., Sorensen R., and Mahler H. R. (1979) Protein phosphorylation in synaptic membranes regulated by adenosine $3^{\prime}: 5^{\prime}$-monophosphate: Regional and subcellular distribution of the endogenous substrates. J. Neurochem. $33,647-659$.

Greengard P. (1976) Possible role for cyclic nucleotides and phosphorylated membrane proteins in post-synaptic actions of neurotransmitters. Nature 260, 101-108.

Greengard P. (1978) Cyclic Nucleotides. Phosphorylated Proteins, and Neuronal Function. Raven Press, New York.

Greengard P. (1979) Cyclic nucleotides, phosphorylated proteins, and the nervous system. Fed. Proc. 38, 2208-2217.

Jones D. J. and McKenna L.F. (1980) Norepinephrinestimulated cyclic AMP formation in rat spinal cord. $J$. Neurochem. 34, 467-469.

Kanof P., Ueda T., Uno I., and Greengard P. (1977) Cyclic Nucleotides and phosphorylated proteins in neuronal function, in Society for Neuroscience Symposia, Vol. 2: Approaches to Cell Biology of Neurons (Cowan W. M. and Ferrendelli J. A., eds), pp. 399-434. Society for Neuroscience, Bethesda.

Kebabian J. W., Petzold G. L., and Greengard P. (1972) Dopamine-sensitive adenylate cyclase in caudate nucleus of rat brain and its similarity to the "dopamine receptor." Proc. Natl. Acad. Sci. 69, 2145-2149.

Kelly D. T., Cotman C. W., and Largen M. (1979) Cyclic AMPstimulated protein kinases at brain synaptic junctions. $J$. Biol. Chem. 254, 1564-1575.

Lohmann S. A., Ueda T., and Greengard P. (1978) Ontogeny of synaptic phosphoproteins in brain. Proc. Natl. Acad. Sci. USA 75, 4037-4041.

Lowry O. H., Rosebrough N. J., Farr A. L., and Randall R. J. (1951) Protein measurement with the Folin phenol reagent. J. Biol. Chem. 193, 265-275.

Neer E. (1979) Interaction of soluble brain adenylate cyclase with manganese. J. Biol. Chem. 254, 2089-2096.

Rawe S. E., Copeland P. M., and Roth R. H. (1977) Segmental norepinephrine and dopamine levels in cat spinal cord. Life Sci. 21, 1409-1416.

Ross E. M., Howlett A. C., Ferguson K. M., and Gilman A. G. (1978) Reconstitution of hormone-sensitive adenylate cyclase activity with resolved components of the enzyme. $J$. Biol. Chem. 253, 6401-6412.

Salomon Y., Londos C., and Rodbell M. (1974) A highly sensitive adenylate cyclase assay. Anal. Biochem. 58, 541-548.

Ueda T. and Greengard P. (1977) Adenosine 3':5'-monophosphate-regulated phosphoprotein system of neuronal membranes. I. Solubilization, purification and some properties of an endogenous phosphoprotein. J. Biol. Chem. 252, $5155-5163$.

Ueda T., Maeno H., and Greengard P. (1973) Regulation of endogenous phosphorylation of specific proteins in synaptic membrane fractions from rat brain by adenosine $3^{\prime}: 5^{\prime}$ monophosphate. J. Biol. Chem. 248, 8295-8305.

Ueda T., Greengard P., Berzins K., Cohen R. S., Blomberg F., Grab D. J., and Sieckevitz P. (1979) Subcellular distribution in cerebral cortex of two proteins phosphorylated by a cAMP-dependent protein kinase. J. Cell Biol. 83, 308-319.

Waible H. (1973) Contribution to the topography of the spinal cord of the Albino rat. Adv. Anat. Embryol. Cell Biol. 47 Fasc. 6, 1-42.

Walter U., Lohman S. M., Sieghart W., and Greengard P. (1979) Identification of the cyclic AMP-dependent protein kinase responsible for endogenous phosphorylation of substrate proteins in synaptic membrane fraction from rat brain. $J$. Biol. Chem. 254, 12235-12239.

Zivin J. A., Reid J. L., Saavedra J. M., and Kopin I. J. (1975) Quantitative localization of biogenic amines in the spinal cord. Brain Res. 99, 293-301. 